\title{
PERFORMANCE OF METAKAOLIN BASED GEOPOLYMER CONCRETE AT ELEVATED TEMPERATURE
}

\author{
S. Gambo ${ }^{1,}{ }^{*}$, K. Ibrahim ${ }^{2}$, A. Aliyu ${ }^{3}$, A. G. Ibrahim ${ }^{4}$ and H. Abdulsalam ${ }^{5}$

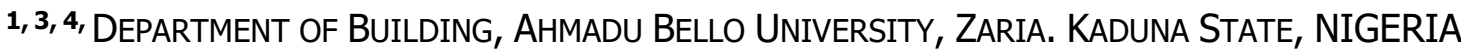 \\ 2, DEPARTMENT OF QUANTITY SURVEYING, UNIVERSITY OF ILORIN, ILORIN, KWARA STATE, NIGERIA

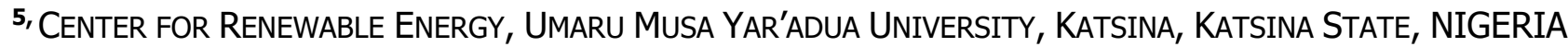 \\ Email addresses: ${ }^{1}$ gambomsc12845@gmail.com, ${ }^{2}$ ibrokb@yahoo.com, ${ }^{3}$ alkasimalyu206@gmail.com, \\ ${ }^{4}$ getsomsc12012@gmail.com, 5 hassandaura@gmail.com
}

\begin{abstract}
Due to the carbon dioxide emission arising from the production of cement, alternative concrete that is environmentally friendly such as metakaolin geopolymer concrete have been developed. However, the performance of metakaolin based geopolymer concrete (MKGC) when exposed to aggressive environment particularly elevated temperature has not been investigated. Therefore, this paper assessed the performance of MKGC exposed to elevated temperatures. MKGC cube specimens of grade 25 were produced using a mix ratio of 1:1.58:3.71.After preparing the specimens, they were placed in an electric oven at a temperature of $60^{\circ} \mathrm{C}$ for 24 hours. Thereafter, the specimens were stored in the laboratory at ambient temperature for 28 days. The specimens were then exposed to elevated temperatures of 200, 400, 600 and $800^{\circ} \mathrm{C}$. After exposure to elevated temperatures, the MKGC specimens were subjected to compressive strength, water absorption and abrasion resistance tests. Results show that at 600 and $800^{\circ} \mathrm{C}$, the MKGC lost a compressive strength of $59.69 \%$ and $71.71 \%$ respectively. Higher water absorption and lower abrasion resistance were also observed.
\end{abstract}

Keywords: Cement, Compressive Strength, Metakaolin Concrete, Elevated Temperature.

\section{INTRODUCTION}

Geopolymer are inorganic aluminosilicate materials synthetized at room temperature or slightly above through alkali activation of reactive aluminosilicate [1]. These silicon and aluminum are dissolved in an alkaline activating solution and subsequently polymerizes in to molecular chain which works as calcium silicon hydrate to bind the aggregate materials $[2,3]$. The reaction of the materials having aluminosilicate with others having alkalis produce a synthetic alkali silicate material called geopolymer [4]. The geopolymerization process involves dissolution of the geopolymer reactants in a strong alkali solution yielding polymeric $\mathrm{Si}-\mathrm{O}-\mathrm{Al}-\mathrm{O}$ bonds in amorphous form [5]. Geopolymer was first introduced by Davidovits in 1978 to describe a family of mineral binders that could cure in alkaline solution as an alternative to conventional Portland cement concrete.
Concrete is the most widely used construction material, and second most consumed material worldwide after water [6]. This is due to numerous advantages it possesses, such as applicability, availability and low cost. However, the manufacturing of cement which is a major binder in concrete leads to global warming. The global warming is caused by the emission of greenhouse gasses such as carbon dioxide $\left(\mathrm{CO}_{2}\right)$ in to the atmosphere [7]. Manufacturing of Portland cement is responsible for the emission of up to 1.5 billion tons of $\mathrm{CO}_{2}$ annually which amounts to $5-8 \%$ of the total $\mathrm{CO}_{2}$ emission which poses a threat to the global climate change [2, 8]. If this trend continues, the rate of carbon emission arising from the production of cement may increase up to $10-15 \%$ by 2020 [9]. Therefore, it is imperative to obtain green concrete as an innovative solution to the aforementioned challenge. One of such solution is geopolymer concrete manufacture which is also

${ }^{*}$ Corresponding author, tel: $+234-803-256-6186$ 
known as zero-cement concrete [8]. Geopolymer concrete has increasingly attracted attention due to its increasingly environmentally beneficial applications as the process of alkali activation will utilize industrial refuse [10]. Geopolymer can be produced by reaction between aluminosilicate materials such as metakaolin, fly ash, granulated blast furnace and alkali activator [2].

Metakaolin is a dehydroxylated form of clay mineral kaolin with coordinated aluminum ion in alumina polyhedron sheet structures [11]. Metakaolin is also a valuable admixture with many excellent advantages including porosity, high specific area, good absorbability and strong coordinated bonds. Metakaolin is produced by heating kaolin at a temperature of $650-900^{\circ} \mathrm{C}$ [12]. During heating process, the structure of kaolinite mineral transforms from crystalline to amorphous which make it a highly reactive pozzalan. This makes metakaolin suitable for the production of metakaolin based geopolymer concrete.

As a newly developed material, metakaolin geopolymer concrete may be exposed to elevated temperatures during fire when it is near electric furnace and reactors [13, 14]. During such exposures the mechanical properties are significantly reduced $[15,16]$. Apart from affecting the mechanical properties, Aijaz, et. al, [17] reported that an elevated temperature reduces durability properties of concrete structures. Hence, it is important to understand the change in the concrete properties due to extreme temperature exposures [18]. Several researches were conducted on the effect of elevated temperature on the properties of geopolymer concrete. For instance, Mateusz, et. al [19] studied the effect of high temperature on mechanical properties of fly ash based geopolymer concrete. Talha [20] and Rivera et al. [21] conducted a research on the performance of fly ash based geopolymer concrete exposed to elevated temperature. However, literature on the effect of elevated temperature on the properties of metakaolin based geopolymer concrete is scarce.

Therefore, this paper seeks to study the effect of elevated temperature on compressive strength, water absorption and abrasion resistance of matakaolins based geopolymer concrete.

\section{MATERIALS AND METHODS}

\subsection{Materials}

The materials used for the study are:

\subsubsection{Metakaolin}

Kaolin was obtained from Kankara Local Government, Katsina State, Nigeria. The Kaolin was calcined at $700^{\circ} \mathrm{C}$ for six hours in order to activate kaolin in to metakaolin. After the metakaolin has cooled down to room temperature, it was sieved through $75 \mu \mathrm{m}$ sieve. The chemical composition of the metakaolin used is presented in Table 1.

\subsubsection{Alkaline Solution}

The alkaline solution was prepared by dissolving $\mathrm{NaOH}$ crystals in water and mixing the resultant solution of $\mathrm{NaOH}$ with $\mathrm{NaSiO}_{3}$. The solution was then stored at room temperature for 24 hours before use. The concentration of $\mathrm{NaOH}$ used is 16 molar concentrations while for $\mathrm{Na}_{2} \mathrm{SiO}_{3}$ the ratio of $\mathrm{Na}_{2} \mathrm{O}$, $\mathrm{SiO}_{2}$ and water as provided by the manufacturer are $14.7 \%, 29.4 \%$ and $55.9 \%$ respectively.

\subsubsection{Water}

The water used for the experiment was clean water fit for drinking which is in compliance with the provisions of [22].

\subsubsection{Aggregates}

The aggregates used for the experiment were fine and coarse aggregates that were in conformity with the provisions of [23]. The fine aggregate used is sharp river sand with a maximum size of $4.75 \mathrm{~mm}$ while the coarse aggregate used is crushed gravel with a maximum size of $20 \mathrm{~mm}$.

\subsection{Mix proportion}

Due to the fact that there is no standard method of mix design for geopolymer concrete, a series of trial tests were conducted in order to establish optimum proportion of materials to be used for the production of geopolymer concrete. After trial test, the mix proportions presented in Table 2 were found to be more suitable and were used for the experiment.

Table 1: Chemical Composition of Metakaolin

\begin{tabular}{llllllllllllll}
\hline Oxides & $\mathrm{Na}_{2} \mathrm{O}$ & $\mathrm{MgO}$ & $\mathrm{Al}_{2} \mathrm{O}_{3}$ & $\mathrm{SiO}_{2}$ & $\mathrm{P}_{2} \mathrm{O}_{5}$ & $\mathrm{SO}_{3}$ & $\mathrm{~K}_{2} \mathrm{O}$ & $\mathrm{CaO}$ & $\mathrm{TiO}_{2}$ & $\mathrm{Mn}_{2} \mathrm{O}$ & $\mathrm{Fe}_{2} \mathrm{O}_{3}$ & $\mathrm{ZnO}$ & $\mathrm{SrO}$ \\
\hline$(\%)$ & 0.045 & 0.496 & 41.43 & 55.98 & 0.250 & 0.313 & 0.728 & 0.056 & 0.083 & 0.008 & 0.608 & 0.002 & 0.001 \\
\hline
\end{tabular}


Table 2: Mix proportion of Materials

\begin{tabular}{llllll}
\hline Sodium silicate & Sodium Hydroxide & Extra water & Metakaolin & Fine aggregate & Coarse aggregate \\
\hline $169 \mathrm{~kg} / \mathrm{m}^{3}$ & $73 \mathrm{~kg} / \mathrm{m}^{3}$ & $3.19 \mathrm{~kg} / \mathrm{m}^{3}$ & $319 \mathrm{~kg} / \mathrm{m}^{3}$ & $506 \mathrm{~kg} / \mathrm{m}^{3}$ & $1182 \mathrm{~kg} / \mathrm{m}^{3}$ \\
\hline
\end{tabular}

\subsection{Preparation of the Samples}

Metakaolin and aggregates were adequately mixed together, after which alkaline solution was added and mixed thoroughly. The fresh metakaolin geopolymer concrete (MKGPC) mix was cast in to a steel mould of $100 \times 100 \times 100 \mathrm{~mm}$ in two layers and each layer was compacted with a poker vibrator. After 24 hours of casting, the concrete cubes were demolded and wrapped with polythene. The specimens were then placed in an electric oven at a temperature of $60^{\circ} \mathrm{C}$ for 24 hours in order to speed up the polymerization reaction as presented in Plate I. Thereafter, the concrete cubes were removed from electric oven and the polythene was removed and concrete cube specimens stored at room temperature for 28 days as presented in Plate II.

The concrete cube samples were then subjected to elevated temperatures of $200,400,600$ and $800^{\circ} \mathrm{C}$ for a period of 2 hours at a heating rate of $10^{\circ} \mathrm{C}$ /minute as presented in figure 1 . After exposure to elevated temperatures the concrete samples were allowed to cool down naturally to room temperature and then subjected to compressive strength, water absorption and abrasion resistance tests. Compressive strength and water absorption tests were carried out in accordance with the provisions of [24] and [25] respectively while abrasion resistance was carried out in accordance with the procedure adopted by [26]

\section{RESULTS AND DISCUSSIONS}

\subsection{Colour Change}

Plate I shows color change for geopolymer concrete samples at elevated temperature. It can be seen that at 27 and $200^{\circ} \mathrm{C}$, the color of the geopolymer concrete specimens is pink. At $400^{\circ} \mathrm{C}$, the color turned dark pink. At 600 and $800^{\circ} \mathrm{C}$ the color changes to dark grey and whitish grey respectively. The color change may be attributed to the oxidation of iron oxide contained in fine and coarse aggregates. This result is in agreement with the findings of Lee, Choi and Hong [27] \& Hager [28] that established that, color change in heated concrete is due to oxidation of iron oxide contained in silicate aggregates.

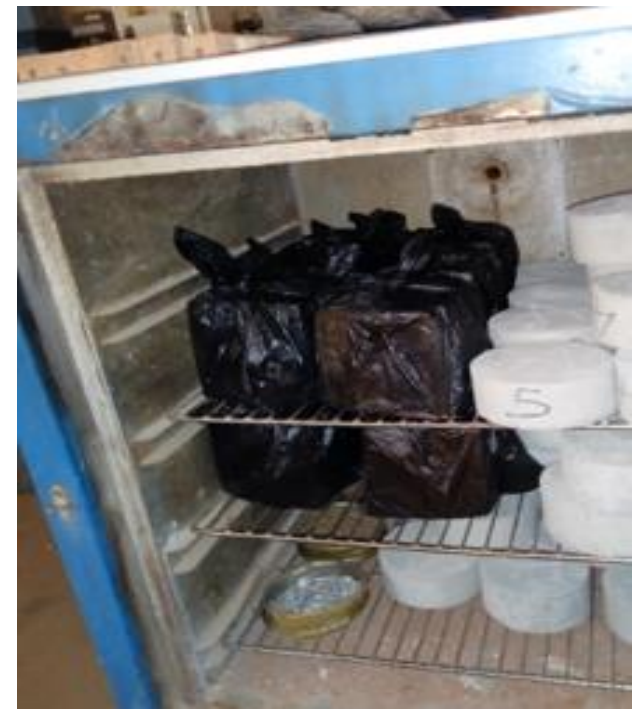

Plate I: MKGPC wrapped and placed in Oven

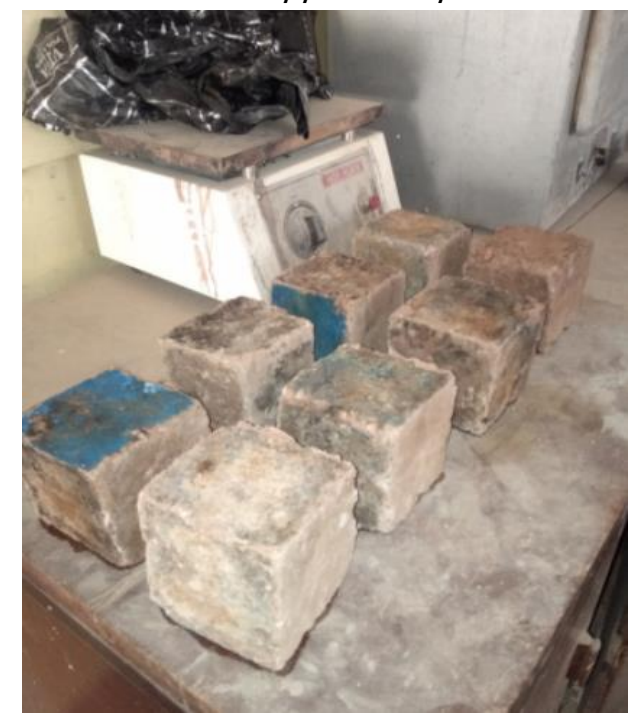

Plate II: MKGPC Removed from Oven

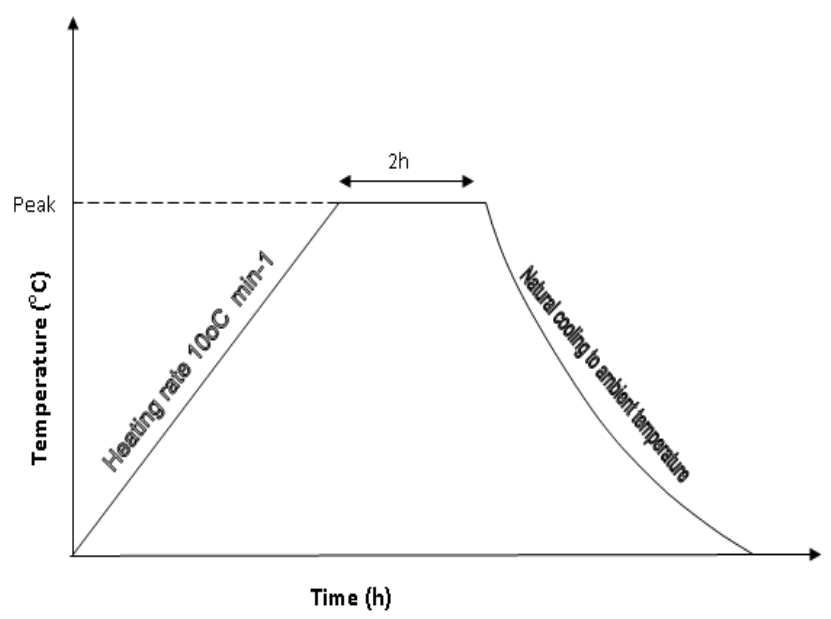

Figure 1: Heating rate for Metakaolin based Geopolymer Concrete Samples 
Since color change is due to temperature rise, the color may be used to reveal the exposure temperature of MKGPC.

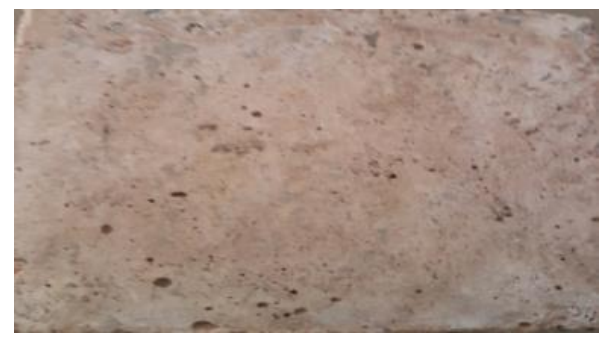

(a) $27^{\circ} \mathrm{C}$

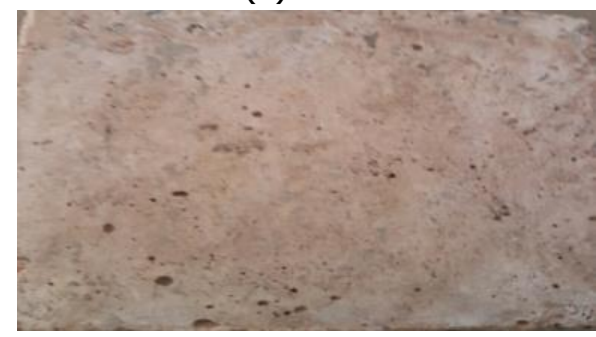

(b) $200^{\circ} \mathrm{C}$

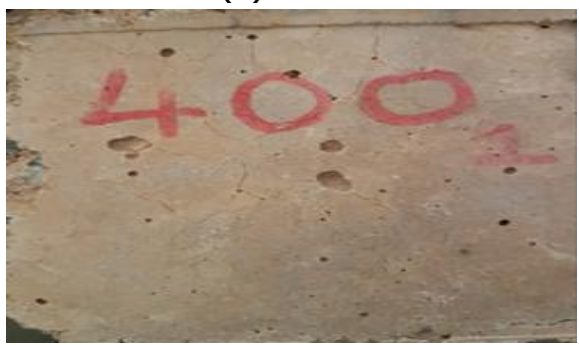

(c) $400^{\circ} \mathrm{C}$

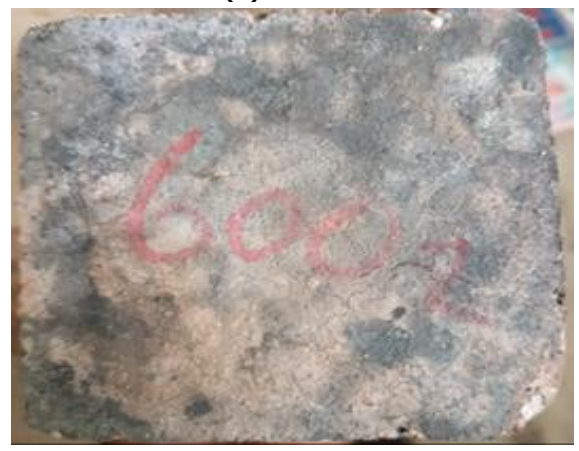

(d) $600^{\circ} \mathrm{C}$

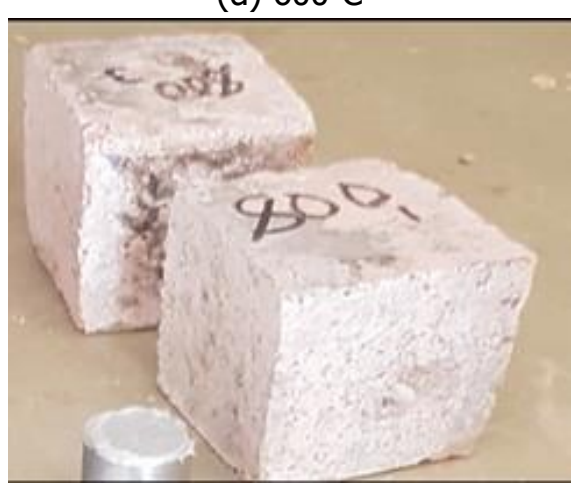

(e) $800^{\circ} \mathrm{C}$

Plate I: Colour Change and Crack Appearance

\subsection{Compressive Strength}

Figure 2 presents the compressive strength of MKGC specimens after exposure to elevated temperature. It can be observed that, the residual compressive strength decreases as the temperature rises. At $27^{\circ} \mathrm{C}$ the MKGPC specimens attained a compressive of $25.8 \mathrm{~N} / \mathrm{mm}^{2}$. At $200^{\circ} \mathrm{C}$, the residual compressive strength decreased to $22.3 \mathrm{~N} / \mathrm{mm}^{2}$. At $400^{\circ} \mathrm{C}, 600^{\circ} \mathrm{C}$, and $800^{\circ} \mathrm{C}$ the residual compressive strength decreased further to $16.8 \mathrm{~N} / \mathrm{mm}^{2}, 10.4 \mathrm{~N} / \mathrm{mm}^{2}$ and $7.3 \mathrm{~N} / \mathrm{mm}^{2}$ respectively. This indicates that, the compressive strength of MKGC declines by $13.57 \%$, $34.88 \%, 59.69 \%$ and 71.71 at 200, 400, 600 and $800^{\circ} \mathrm{C}$ respectively. The reduction in compressive strength could be attributed to the partial decomposition of alkaline materials (sodium silicate and sodium hydroxide) that bind the aggregates together. This is in conformity with the findings of Talha [20].

\subsection{Water Absorption}

Figure 3 depicts water absorption of MKGC exposed to elevated temperatures. The water absorption increases as the temperature rises. At $27^{\circ} \mathrm{C}$, water absorption of MKGC specimen is $3.6 \%$. After exposure to $200^{\circ} \mathrm{C}$, water absorption increased to $4.9 \%$. At 400,600 and $800^{\circ} \mathrm{C}$, the percentage of water absorption increased to $5.35 \%, 6.43 \%$ and $7.96 \%$ respectively. The higher water absorption observed at elevated temperature could be due to the formation of pores as a result of the partial decomposition of alkaline materials.

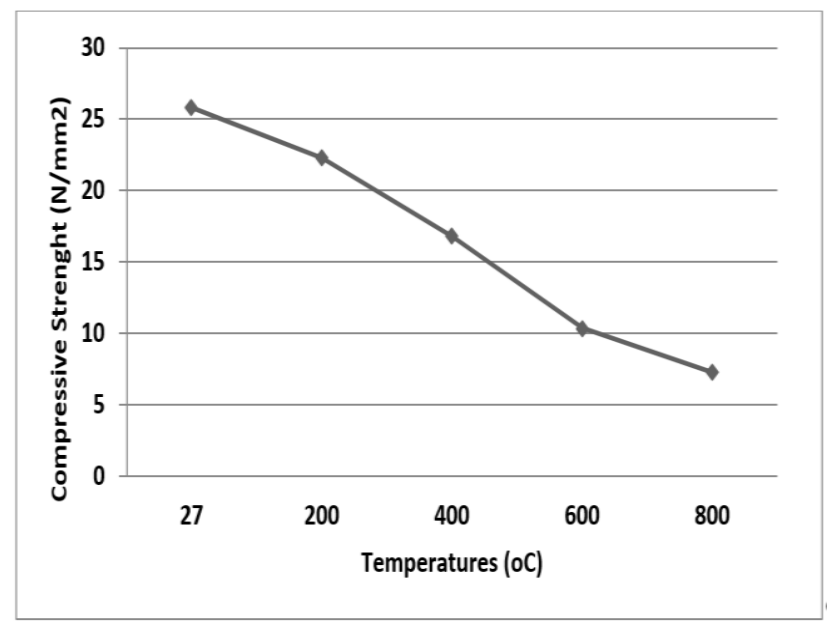

Figure 2: Residual Compressive Strength of Metakaolin Geopolymer Concrete 


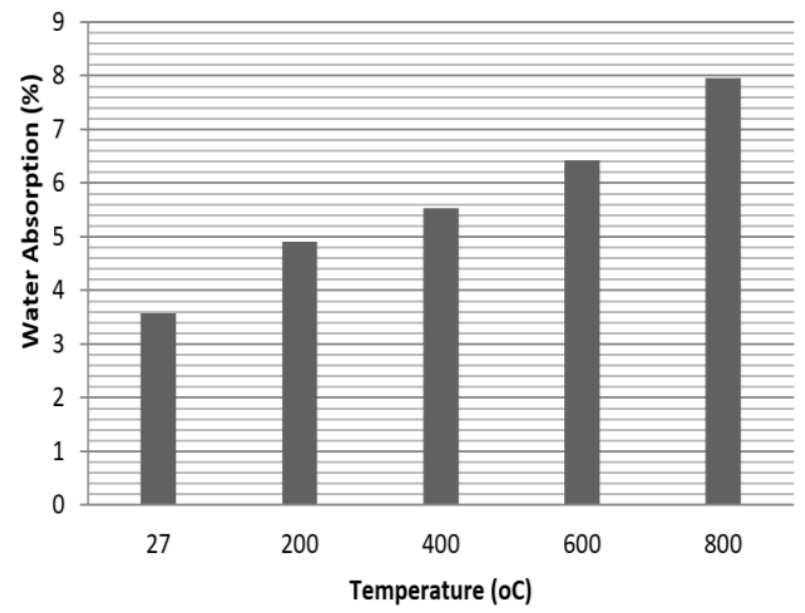

Figure 3: Water Absorption of Metakaolin Geopolymer Concrete Specimens a

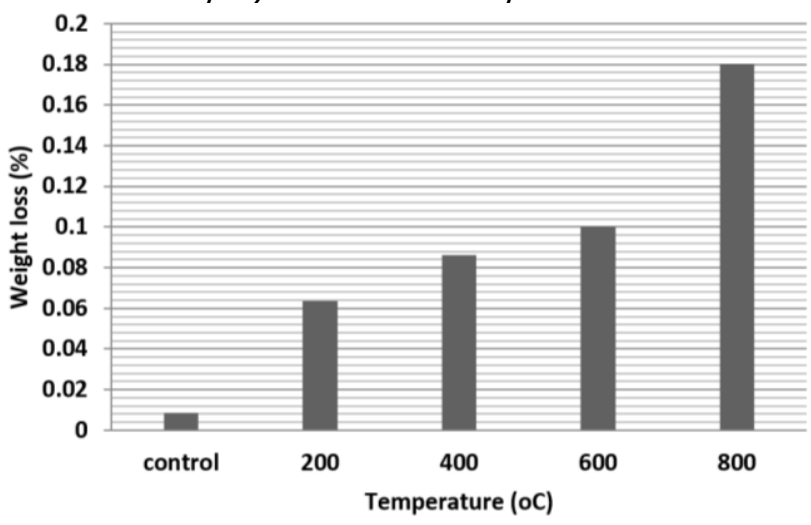

Figure 4: Abrasion Resistance of MKGC Samples Exposed to Elevated Temperature

\subsection{Abrasion Resistance}

Figure 4 shows the abrasion resistance of MKGC specimens exposed to elevated temperatures expressed as percentage loss of weight. The loss of weight increased as the temperature rises. At $200^{\circ} \mathrm{C}$, the MKGC loss a weight of $0.06 \%$. At 400,600 and $800^{\circ} \mathrm{C}$ the loss of weight increased to $0.08 \%, 0.10 \%$ and $0.18 \%$ respectively.

\section{CONCLUSIONS}

i. The color change may be used to reveal the temperature to which metakaolin based geopolymer concrete was exposed to.

ii. Compressive strength decreases as the temperature rises due to partial decomposition of sodium silicate.

iii. Water absorption of metakaolin geopolymer concrete increased as the temperature rises while abrasion resistance decreased.

\section{REFERENCES}

[1] Pavel, R. \& Kristyna, S. Thermal Behavior of Metakaolin/Fly Ash Geopolymer with Chamotte Aggregate. MDPI Materials Journal, Vol. 9(2016), pp $1-13,2016$.

[2] Kamal, N., Des, C. \& Paul, K. High Strength Geopolymer Concrete - Properties, Advantages and Challenges. Advances in Materials Vol. 7, No. 2, pp $15-25,2018$.

[3] Abdulaleem, M.I. \&Arumairaj, P.D. Geopolymer Concrete - A Review. International Journal of Engineering Sciences and Emerging Technologies, Vol. 1, No. 2, pp 118-122, 2012.

[4] Basil, S.A., Tareq, S.A. \& Zaid, H. Effect of Curing System on Metakaolin Based geopolymer Concrete. Journal of Babylon University, Vol. 3, No. 24, pp $1-8,2016$.

[5] Hani, A., Dalu, Z., Mijia, Y. \& Zhili, G. Early Strength and Durability of Metakaolin based Geopolymer Concrete. Magazine of Concrete Research, Vol. 69, No. 1, pp $46-54,2017$

[6] Meyer, C. (2005) Concrete as Green Building Material. Proceedings of the Third International Conference on Construction Materials "Conmat $05^{\text {" }}$ Vancouver, Canada, $22^{\text {nd }}-25^{\text {th }}$ August.

[7] Ragnan, B.V. Geopolymer Concrete for Environmental Protection. Indian Concrete Journal, Vol. 88 No. 4, pp 41 - 48, 2014.

[8] Ekaputri, J.J., Junaedi, S. \& Wijaya. Effect of Curing Temperature and Fiber on Metakaolin Based Geopolymer. Proceedings of Sustainable Engineering Structures and Construction Materials, Vol. 171, No. 2017, pp 572-583, 2017.

[9] Wasan, I.K., Qais, J.F. \& Mahmod, F.A. Evaluation of Sustainable Metakaolin Geopolymer Concrete with Crushed Waste Clay Brick. Proceedings of the $2^{\text {nd }}$ International Conference on Sustainable Engineering Techniques (ICSET, 2019), pp 1- 9, 2019.

[10] Tao, L., Qingyuan, W., Zhongwei, G., Yu, C. \&Xiaoshuang, S. Deterioration and Evolution of the Fly Ash Geopolymer Concrete Against $\mathrm{MgSO}_{4}$ Solution. Advances in Material Science and Engineering, pp 1 - 11, 2017.

[11] Liang, C., Zaiqun, W., Yuanyi, W. \& Jing, F. Preparation and Properties of Alkali Activated Metakaolin based Geopolymer. MDPI Materials, Vol. 9 (2016), pp 1 - 12, 2016.

[12] Ibrahim, A.G., Okoli O.G. \& Dahiru, D. Comparative Study of the Properties of Ordinary 
Portland cement Concrete and Binary Concrete Containing Metakaolin Made from Kankara Kaolin Nigeria. ATBU Journal of Environmental Technology, Vol. 9 No. 2, pp. 53 - 59, 2016.

[13] Arioz, O. (2007). Effect of Elevated Temperature on the Properties of Concrete. Fire Safety Journal, Vol. 42(2007), pp 516-522, 2007.

[14] Amrutha, Gopintha, N., Mattur, N. \& Rajeeba, S. (2011). High Temperature Performance of Self Compacting High Volume Fly Ash Concrete Mixes. Journal of Structural Fire Engineering, Vol. 2 No. 2, pp 81-90, 2011.

[15] Chowdury, S.H. (2014). Effect of Elevated Temperature on Mechanical Properties of High Strength Concrete. $23^{\text {rd }}$ Australian Conference on the Mechanics of Structures and Materials (ACMSM 23), Bryon Bay Australia, 9-12 December, 2014, pp 1078-1082.

[16] Koksal, F., Gencel, O., Brostow, W \&Hagg, H.E.L. Effect of High Temperature on Mechanical and Physical Properties of Light Weight Cement Based Refractory Including Expanded Vermiculite. Materials Research Innovations, Vol. 16 No. 1, pp 7-13. 2012.

[17] Aijaz, Z., Kulkarni, A. \& Aslam, H. Behavior of Reinforced Concrete Subjected to High Temperature - A Review. Journal of Structural Fire Engineering, Vol. 4 No. 4, pp 281-295, 2013.

[18] Vasusmitha, R. \& Srinvaja, P.R. Effect of Elevated Temperature on High Strength Self Compacting Concrete. International Journal of Engineering Research and Technology, Vol. 1 No. 8, pp 1-10, 2012.

[19] Mateusz, S., Izabela, H. \&Joanna, K. Effect of High Temperature on Mechanical Properties of Geopolymer Concrete. MATEC Web Conferences, 163, 06004 (2018), MATBUD 2018.

[20] Talha, M.J. Performance of Geopolymer Concrete at Elevated Temperatures. (PhD Thesis) 2015.
Retrieved

from http://unsworks.unsw.edu.au/fapi/datastrea m/unsworks:35540/SOURCE02?view=true

[21] Rivera, O.G., Long, W.R., Weiss Jr. C.A., Moser, R.D., Williams, B.A., Torres, K.C., Gore, E.R. \& Allison, P.G. Effect of Elevated Temperature on Alkali Activated Polymeric Binder Compounds Compared to Portland cement based Binders. Cement and Concrete Research, Vol. 90 (2016), pp $43-51,2016$.

[22] BS EN 1008 (2002). Mixing Water for Concrete. Specification for Testing and Assessing the Suitability of Water. BSI, Linford wood, Milton Keynes MK14 6LE, UK.

[23] BS EN 12620 (2013). Aggregates for Concrete. BSI, Linford wood, Milton Keynes MK14 6LE, UK.

[24] BS EN 12390-3 (2009). Testing Hardened Concrete. Compressive Strength of Test Specimen. BSI, Linford wood, Milton Keynes MK14 $6 \mathrm{LE}, \mathrm{UK}$.

[25] BS 1881-122:2011. Testing of Hardened Concrete. Method for the Determination of Water Absorption. BSI, Linford wood, Milton Keynes MK14 6LE, UK.

[26] Gambo, S. Development of Models for the Prediction of Durability Properties of Concrete Based on Non-destructive Testing Method. Doctoral Thesis Ahmadu Bello University, Zaria, Nigeria, 2019.

[27] Lee, J., Choi, K. and Hong, K. (2009). Color and Material Property Change in Concrete Exposed to High Temperatures. Journal of Asian Architecture and Building Engineering Vol. 8, No. 1, pp 175 182, 2009.

[28] Hager, I. (2014). Color Change in Heated Concrete. Journal of Fire Technology, Vol. 50, pp $945-958,2014$. 